This report is based on the analysis of data from experimental plots in stands of considerable heterogeneity in which the purpose was to investigate the effect of fertilizer on cone production and not from an experiment designed to measure volume response. This limitation must be clearly recognized in examining the regression analyses and the conclusions. Publication of these results is best justified by the fact that these are the only plots in Douglas-fir in British Columbia fertilized so long ago.

\title{
Forest nutrition studies in Douglas-fir on Vancouver Island:
}

\section{A second report}

\author{
D. L. HANDLEY \\ MacMillan Bloedel Limited, Forestry Division, Nanaimo, B.C. \\ L. V. PIENAAR \\ Forest and Range Management, Washington State University, Pullman, Wash.
}

Etude sur la nutrition des forêts de l'île de Vancouver un deuxième rapport. Les données de 33 parcelles établies dans des perchis de Pseudotsuga de Menzies et qui avaient recu des applications d'azote variant de 0 à $335 \mathrm{lb} / \mathrm{ac}$ ont été analysées par régression pour des périodes de 5 et 11 ans suivant l'application d'engrais. Malgré certaines lacunes dans le dispositif expérimental et de certaines données, il a été possible de mettre en relief un accroissement périodique accru du diamètre et du volume avec l'augmentation des quantités d'azote ajouté.

Le volume total a augmenté, de façon linéaire, avec, à la fois, la quantité d'azote employé et la qualité de station, pour décroître subséquemment les années écoulées depuis le traitement. Pour la période de 5 ans, l'accroissement annuel courant se chiffrait à 29 pi. cu./ac pour chaque $100 \mathrm{lb}$ d'azote ajouté pour une qualité de station de 70 , alors qu'il s'élevait à $42 \mathrm{pi}$. cu./ac pour une qualité de station de 100. Pour la période de 11 ans, les volumes correspondants furent de 25 et $36 \mathrm{pi}$. cu./ac respectivement.

MacMillan Bloedel initiated a series of forest nutrition studies in natural stands of Douglas-fir, Pseudotsuga menziesii (Mirb.) Franco, on Vancouver Island between the fall of 1954 and spring of 1958 (Crossin et al. 1966). The first experiment, laid out in the fall of 1954 and spring of 1955, was exploratory in nature and was designed to test the effect of the major nutrients, singly and in combination, and the more common trace elements on tree growth. Response to fertilizers containing nitrogen was evident soon after application and 1955 height growth was dramatically increased. Three subsequent experiments, established in 1955, 1956 and 1957, were designed to determine the effect of the form of nitrogen used, the level of nitrogen applied and combinations of forms and levels. Following an observation in the fall of 1955 that some of the trees treated with ammonium nitrate bore more cones than those receiving the other treatments, a series of cone stimulation experiments was established between November 1955 and June 1958. All treatments contained nitrogen in some form, alone or combined with other major nutrients (Stoate et al. 1961).

The majority of the experiments, comprising 908 individual treatments or plots, were located in stands less than $20 \mathrm{ft}$ tall and, in most cases, were representative of the average and lower sites, i.e. below site index 80 (base 50 years breast-height age), because response was expected to be most obvious on poor sites and most easily measured on small trees. However, 18 replications of four cone stimulation and four general nutrition experiments were established in stands exceeding $20 \mathrm{ft}$ tall and covering a range of site index up to 115 .

Soils on the study area, which is within a $\mathbf{3 0}$ mile radius of Nanaimo, are predominantly red-brown, sandy to gravelly loams developed from glacial tills and drifts. In general they are characterized by a high proportion of gravels and stones and also by depths of less than 30 inches to the compacted glacial till or "hardpan'.

By 1966, forest companies in the Pacific Northwest had recognized that fertilization offered a means of maintaining, or even increasing, present levels of allowable annual cut, but basic data for use in economic analyses were lacking. MacMillan Bloedel then entered into a cooperative agreement with the College of Forest Resources, University of Washington to investigate the increase in volume and the duration of response from a single application of fertilizer. MacMillan Bloedel Limited collected the data and the University did all compilation. The analyses were undertaken subsequently by $L$. V. Pienaar. This report gives a tentative indication of the expected volume-gain from a single application of nitrogenous fertilizer on pole-sized Douglas-fir stands.

\section{The plots and data collection}

When these experiments were established, it was planned to measure response on a tree rather than a plot basis. Ten dominant trees were selected randomly on each plot. Where stand height was less than $20 \mathrm{ft}$, height only was measured. In taller stands only diameter was measured. Since measurement of response was not an objective of the cone stimulation experiment no trees were meas- 
ured. Therefore, though all plots were carefully laid out on the ground as 0.1 acre squares, no special effort was made to select for uniformity of age, composition or site index as would have been done if the program had been designed to measure volume response.

The first step was a field check of the 18 replications potentially suitable for remeasurement. Ten of these were rejected outright because of extreme heterogeneity, a further replication was rejected after measurement because site index fell below the $50 \mathrm{ft}$ minimum recognized by King (1966). Of the seven remaining replications, all in cone stimulation experiments and comprising a total of 43 plots in five stands of almost pure Douglas-fir, all plots on two were sufficiently homogenous to be retained as complete installations. In the others, one or more plots had to be rejected because of excessive variation in stocking and site index.

Since none of the plots had been completely inventoried at the time of fertilization, ten trees were felled on each plot to sample the range of diameters and the following measurements taken: heights and $\mathrm{dbh}$ inside bark five years previous to, at the time of, and five years after fertilization, as well as at the end of 1967; dbh outside bark, fall 1967; and breastheight age, fall 1967. All remaining living trees over 1.55 inches $\mathrm{dbh}$ were tagged, $\mathrm{dbh}$ was measured to the nearest 0.1 inch, and eight to ten additional height sample trees, representative of the range of diameter, were measured on each plot. Average age at breast-height ranged between 26 and 36 years at the end of 1967.

Relationships between past and 1967 inside bark diameters, as determined from the sample trees for each plot, were used to reconstruct past diameter tallies for the plots, and thence to obtain basal area and numbers of stems per acre at the time of fertilization.

Some idea of the variation in plot data may be obtained from the following ranges in the basic data compiled for the year treatment commenced:

mean dbh: 3.1 to 5.5 inches

stems per acre over 1.5 inches dbh: 390 to 1,450

basal area of trees over 1.55 inches $\mathrm{dbh}: 44.3$

to $187.5 \mathrm{sq} f \mathrm{ft}$ per acre

volume of trees over 1.55 inches dbh: 587 to $3,378 \mathrm{cu} \mathrm{ft}$ per acre

age at breast height: 15 to 25 years

Site index ranged between 70 and 115 , or approximately 80 to 140 on base age of 100 years, for all plots and varied by as much as $33 \mathrm{ft}$ on contiguous plots in two of the five stands.

\section{Fertilization data}

Ammonium nitrate $\left(33^{1 / 2} / 0 / 0\right)$ was most commonly used as the $\mathrm{N}$ source in these plots. Others were ammonium phosphate $(16 / 20 / 0)$, ammonium sulphate $(21 / 0 / 0)$, NPK $(10 / 20 / 20$, calcium nitrate $(151 / 2 / 0 / 0)$, and sodium nitrate $(16 / 0 / 0)$. The type of fertilizer, approximate weights of nitrogen, years since application and plot distribution of the 33 plots analysed are shown in Tables 1 and 2 . Distribution within the fir stands is shown in Table 3. Times of application ranged from mid October to early July, but most treatments were made in April.

TABLE 1. Distribution of sample plots by fertilizer and approximate weight of nitrogen applied

\begin{tabular}{|c|c|c|c|c|c|c|c|}
\hline \multirow[b]{2}{*}{ Treatment } & \multirow[b]{2}{*}{ Analysis } & \multicolumn{5}{|c|}{ Pounds of nitrogen per } & \multirow{2}{*}{ Total } \\
\hline & & & 130 & $\begin{array}{l}\text { acre } \\
165\end{array}$ & 260 & 335 & \\
\hline $\begin{array}{l}\text { Ammonium phos } \\
\text { phate-sulphate }\end{array}$ & $16 / 20 / 0$ & 一 & 1 & - & 3 & - & 4 \\
\hline Ammonium & $21 / 0 / 0$ & - & 1 & 2 & 一 & 2 & 5 \\
\hline $\begin{array}{l}\text { Ammonium } \\
\text { nitrate }\end{array}$ & $331 / 2 / 0 / 0$ & - & 4 & - & 5 & 一 & 9 \\
\hline $\begin{array}{l}\text { NPK } \\
\text { Calcium nitrate }\end{array}$ & $10 / 20 / 10$ & - & $\overline{1}$ & $\underline{4}$ & 二 & 二 & $\begin{array}{l}4 \\
1\end{array}$ \\
\hline $\begin{array}{l}\text { Calcium nitrate } \\
\text { Sodium nitrate }\end{array}$ & $\begin{array}{l}151 / 2 / 0 / 0 \\
16 / 0 / 0\end{array}$ & - & 1 & - & - & 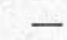 & \\
\hline Control & & 9 & - & - & - & - & 9 \\
\hline otal & & 9 & 8 & 6 & 8 & 2 & 33 \\
\hline
\end{tabular}

TABLE 2. Distribution of sample plots for years since treatment and weight of nitrogen applied

\begin{tabular}{|c|c|c|c|c|c|c|}
\hline Years & 0 & $\begin{array}{r}\text { Pounds of } \\
124-133\end{array}$ & $\begin{array}{l}\text { nitroge } \\
160-168\end{array}$ & $\begin{array}{c}\text { n per acre } \\
256-266\end{array}$ & 335 & Total \\
\hline $\begin{array}{l}12 \\
11 \\
10\end{array}$ & $\begin{array}{l}2 \\
6 \\
1\end{array}$ & $\begin{array}{c}\overline{5} \\
3\end{array}$ & $\begin{array}{r}1 \\
5 \\
-\end{array}$ & $\begin{array}{r}2 \\
6 \\
-\end{array}$ & $\underline{-}$ & $\begin{array}{r}5 \\
24 \\
4\end{array}$ \\
\hline Total & 9 & 8 & 6 & 8 & 2 & 33 \\
\hline
\end{tabular}

Following the early assessments of the MacMillan Bloedel experiments, T. N. Stoate stated in his annual report for 1959 "that no additional element has been found to cause any increased growth when used with nitrogen and that no one form of nitrogen has been found to be better than any other." These conclusions were based on analysis of height increments of individual sample trees three and four growing seasons after fertilization.

The first conclusion in particular is open to argument. Walters (1964) obtained response from phosphate and sulphate in nursery seedlings, hence there could be an increased effect when used in combination with nitrogen. Detailed examination of the Forms and Levels of Nitrogen Experiments planned for 1972 and 1973 should clarify the position. In the following analyses, it was assumed that

TABLE 3. Distribution of plots by stand and fertilizer treatment

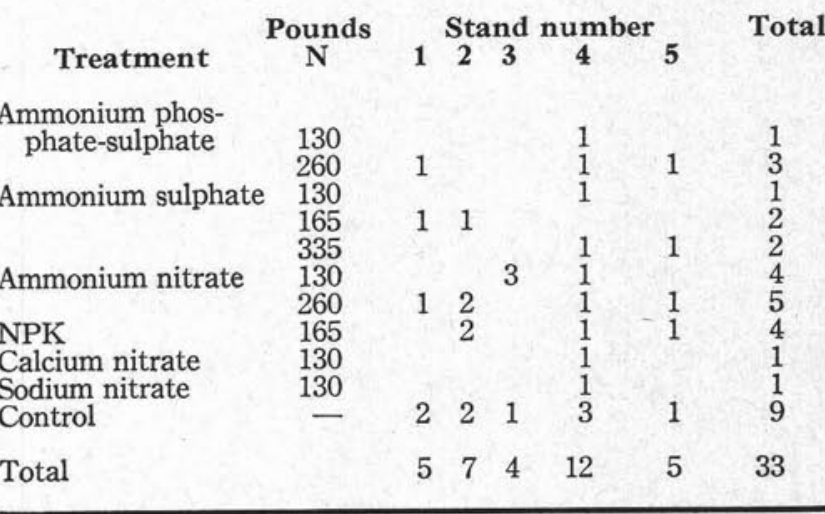


response to $\mathrm{N}$ was similar regardless of form and that any additive effect of the other elements was at most small enough so as not to affect seriously the results.

\section{Analysis of the data}

The data were examined in two ways. Firstly, the effects of fertilization on diameter growth were assessed and then volume response was analysed.

Effects of fertilization on diameter growth. The diameter data from the felled sample trees were subjected to a regression analysis using a model of the general form:

$$
\mathrm{y}=\mathrm{a}_{0}+\mathrm{a}_{1} \mathrm{x}_{1}+\mathrm{a}_{2} \mathrm{x}_{2}+\mathrm{a}_{3} \mathrm{x}_{3}+\mathrm{a}_{4} \mathrm{x}_{4}+
$$

where $\mathrm{y}=$ periodic $\mathrm{dbh}$ growth inside bark in inches, and the explanatory (independent) variables were:

$\mathrm{x}_{1}=\mathrm{dbh}$ inside bark in inches (at time of fertilization for $\mathrm{y}_{1}$ and $\mathrm{y}_{2}$, and at 5 years after fertilization for $\mathrm{y}_{3}$ )

$\mathrm{x}_{2}=$ site index (breast height age 50) at time of treatment

$\mathrm{x}_{3}=$ basal area per acre in sq $\mathrm{ft}$ (for trees over 1.55 inches dbh inside bark)

$\mathrm{x}_{4}=$ pounds of nitrogen per acre

$\mathrm{x}_{5}=$ site index multiplied by pounds of nitrogen per acre i.e. $\mathrm{x}_{2} \cdot \mathrm{x}_{4}$

$\mathrm{x}_{6}=\mathrm{x}_{3}$ divided by stems per acre over 1.55 inches in 1967, i.e. an approximate measure of average tree size but subject to the confounding effects of ingrowth and mortality.

The analysis was conducted in three stages for each of the five stands and with all data pooled. In the first stage, total diameter growth inside bark for the first five years after fertilization was used as the dependent variable $\left(\mathrm{y}_{1}\right)$; in the second, total diameter growth for the entire period following fertilization $\left(y_{2}\right)$ was used; in the third stage the total diameter growth from five years after fertilization to the end of $1967\left(y_{3}\right)$ was used as the dependent variable.

The regression equations for the pooled data only are given below. Only variables significant at the $5 \%$ level are included in the regression equations.

$\mathrm{y}_{1}=-0.1981+0.1779 \mathrm{x}_{1}+0.0069 \mathrm{x}_{2}-0.0043 \mathrm{x}_{3}$

$$
+0.0014 \mathrm{x}_{4}\left(\mathrm{R}^{2}=.50, \mathrm{SE}=0.32\right)
$$

$\mathrm{y}_{2}=-1.5866+0.4544 \mathrm{x}_{1}+0.0142 \mathrm{x}_{2}+0.0025 \mathrm{x}_{4}$ $\left(\mathrm{R}^{2}=.55, \mathrm{SE}=0.65\right)$

$\mathrm{y}_{3}=-0.5925+0.2904 \mathrm{x}_{1}+0.0069 \mathrm{x}_{2}+0.0004 \mathrm{x}_{4}$

$-3.14 \mathrm{x}_{6}\left(\mathrm{R}^{2}=.55, \mathrm{SE}=0.30\right)$

Note: in $\mathrm{y}_{3}, \mathrm{x}_{1}$ is $\mathrm{dbh}$ at five years after fertilization.

Initial dbh was the most important, single variable in explaining growth differences in the regression model. Basic design deficiencies and absence of measured initial data were compounded by considerable between-plot variation in site index and stocking; this resulted in a variety of results regarding the importance of the other variables in the analysis for the $\mathbf{5}$ individual stands. However, when the data were pooled, periodic diameter growth rate increased with increasing site index and weights of nitrogen for both the 5- and 11-year pe- riods, although in $y_{3}$ there is an indication, since the $\mathrm{X}_{4}$ co-efficient is very small, that the effect was decreasing in the second portion of the 11-year period.

Effect of fertilization on volume growth. Total and merchantable volume at the end of 1967 were calculated from the basic plot data. Merchantability limits used were 1 -ft stump and 4-inch top diameter inside bark.

Estimates of past diameter tallies and height-diameter relationships were derived from the felled sample tree data and the 1967 diameter tallies. Total and merchantable volumes at time of treatment and five years later were calculated from these estimates.

Total and merchantable periodic annual increment (p.a.i.) were calculated on a 5 year basis and on either a 10, 11 and 12 year basis depending on plot history as summarized in Table 2.

Linear regression was used to analyse the p.a.i. in an attempt to test the statistical significance of different levels of nitrogen on growth. The regression model was again of the following general form:

$$
\mathrm{y}=\mathrm{a}_{0}+\mathrm{a}_{1} \mathrm{x}_{1}+\mathrm{a}_{2} \mathrm{x}_{2}+\mathrm{a}_{3} \mathrm{x}_{3}+\mathrm{a}_{4} \mathrm{x}_{4}+\mathrm{a}_{5} \mathrm{x}_{5}+\mathrm{a}_{6} \mathrm{x}_{6}
$$

in which

$\mathrm{y}=$ periodic annual cubic volume increment $\left(\mathrm{ft}^{2} /\right.$ acre/year)

and

$\mathrm{x}_{1}=$ breast-height age at treatment

$\mathrm{x}_{2}=$ site index at treatment

$\mathrm{x}_{3}=$ basal area per acre at treatment (over 1.55 inches dbh) divided by stems per acre over 1.55 inches dbh in 1967, i.e. an approximate measure of average tree size but subject to confounding due to ingrowth and mortality.

$\mathrm{x}_{4}=$ volume in $\mathrm{ft}^{3} /$ acre at treatment (either total or merchantable, as stated)

$\mathrm{x}_{5}=$ pounds of nitrogen per acre

$\mathrm{x}_{6}=$ site index multiplied by pounds of nitrogen per acre, i.e. $\mathrm{x}_{2} \cdot \mathrm{x}_{5}$

The analysis was conducted in two stages; in the first, $y_{1}$ represents the p.a.i. for the first 5 years of treatment, in the second, $y_{2}$ represents the p.a.i. for the entire post-treatment period.

The following regression equations were obtained for the pooled data:

\section{total cubic volume}

$$
\begin{aligned}
\mathrm{y}_{1}= & 310.8+0.1436 \mathrm{x}_{4}+0.0042 \mathrm{x}_{6}-13.03 \mathrm{x}_{1} \\
\mathrm{y}_{2}= & 50.06+0.10 \mathrm{\textrm {x } _ { 3 }}\left(\mathrm{R}^{2}=.81, \mathrm{SE}=42.3\right) \\
& \left(\mathrm{R}^{2}=.81, \mathrm{SE}=39.2\right)
\end{aligned}
$$

merchantable cubic volume

$$
\begin{aligned}
\mathrm{y}_{1}= & 229.1+0.1767 \mathrm{x}_{4}+0.0031 \mathrm{x}_{6}+8.904 \mathrm{x}_{1} \\
& \left(\mathrm{R}^{2}=.72, \mathrm{SE}=48.7\right) \\
\mathrm{y}_{2}= & 388.7+0.2326 \mathrm{x}_{4}+0.0031 \mathrm{x}_{6}-9.972 \mathrm{x}_{1} \\
& -1147.0 \mathrm{x}_{3}\left(\mathrm{R}^{2}=.69, \mathrm{SE}=55.0\right)
\end{aligned}
$$

As might be expected, initial volume was the most important variable in explaining periodic annual volume growth in these young stands. The effect of nitrogen is explained as an interaction with site. 
Figures 1 and 2 show the interaction of nitrogen and site index on p.a.i. Total volume p.a.i. increases per $100 \mathrm{lb}$ of $\mathrm{N}$ ranged from a low of $25 \mathrm{ft}^{3} /$ acre over the 11-year period for site index 70 to $36 \mathrm{ft}^{3} /$ acre for site index on p.a.i. Total volume p.a.i. increase per 5 -year period for the same site indices.

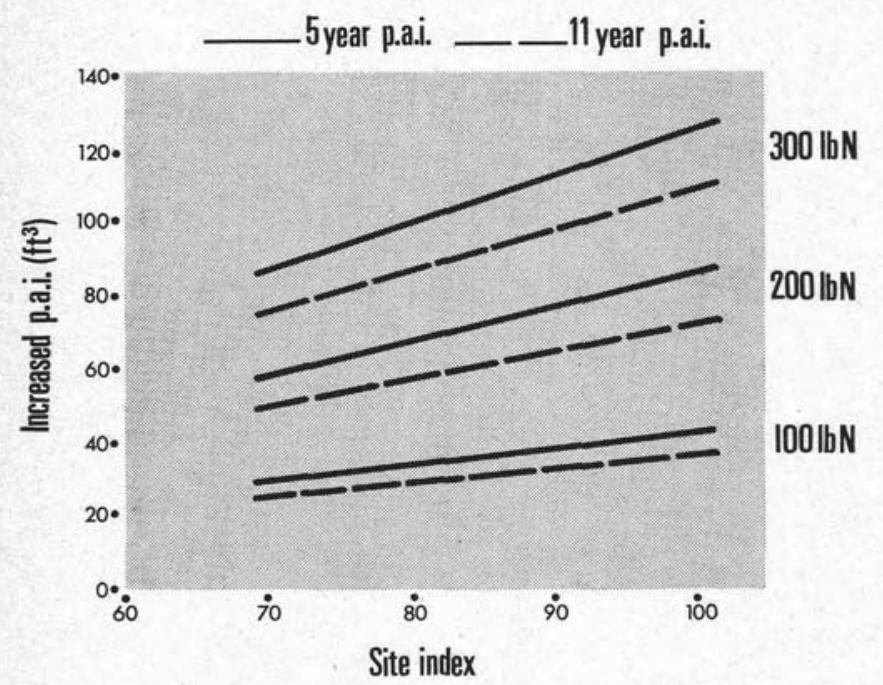

Fig. 1. Increased total volume periodic annual increment per hundred pounds of nitrogen.

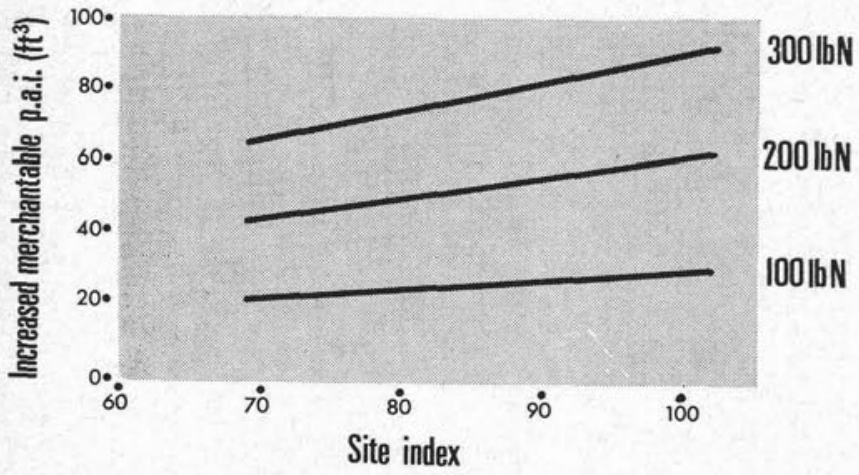

Fig. 2. Increased merchantable volume periodic annual increment per hundred pounds of nitrogen for 11 year period.
Merchantable volume p.a.i. increase ranged from $22 \mathrm{ft}^{3} /$ acre to $31 \mathrm{ft}^{3} /$ acre per $100 \mathrm{lb}$ of $\mathrm{N}$ for the same site indices. There was no difference between the 5-and 11-year periods. The fact that response did not decrease over time is attributed to the comparatively rapid ingrowth into the merchantable size class during the second half of the observation period. For example, p.a.i. in the control plots was $60 \%$ greater for the 11 years than for the first 5 years.

\section{Conclusions}

The following tentative conclusions are drawn from the results and are offered as interim guidelines for use in planning, pending availability of results from experiments designed for the purpose.

- The application of nitrogenous fertilizers significantly affects both diameter and volume growth of young, pole-sized Douglas-fir stands.

- The stimulating effect of nitrogen on volume growth appears to increase with site index over the range of site indices from 70 to 100 .

- For each $100 \mathrm{lb}$ of nitrogen applied the increase in total annual volume increment ranges from 25 to $36 \mathrm{ft}^{3} /$ acre over a 5 year period, as site index increases from 70 to 100 .

- There is no evidence of a significant change in the rate of stimulation from nitrogen with increasing weights up to $335 \mathrm{lb} /$ acre.

- The stimulating effect of nitrogen on volume growth apparently persisted for 10 to 12 years but, though insignificant, showed a decreasing trend with time.

\section{References}

CROSSIN, E. C., J. A. MARLOW and G. L. AINSCOUGH. 1966. A progress report on forest nutrition studies on Vancouver Island. Forest. Chron. 42:265-284.

KING, J. E. 1966. Site index curves for Douglas fir in the Pacific Northwest. Weyerhaeuser Forestry Pap. No. 8. 49.

STOATE, T. N., I. S. MAHOOD and E. C. CROSSIN. 1961. Cone production in Douglas fir. Empire Forest. Rev. 40:105-110.

WALTERS, J. 1964. Some observations on the juvenile growth of western hemlock in plantations. Univ. British Columbia, Fac. Forest. Res. Pap. No. 61. 12 p.

\section{F O R E S T A L}

FORESTRY AND ENGINEERING INTERNATIONAL LIMITED

\section{FORESTA L \\ FORESTRY AND ENGINEERING LIMITED}

\author{
VANCOUVER 5, CANADA \\ 1409 WEST PENDER STREET \\ Cable: FORESTAL
} Tel.: 683-6994

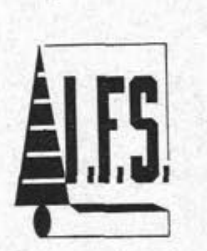

CONSULTING

FORESTERS

ENGINEERS
Industrial Forestry Service Ltd.

101-1595 FIFTH AVE., PRINCE GEORGE, B.C.

TEL.: 563-9207 